\title{
PEMBELAJARAN PKN DI SEKOLAH DASAR
}

\author{
Christi Yanti \\ Nim.836401807 \\ email: christi.yanti2606@gmail.com
}

\section{Pendahuluan}

Pengenalan nilai dengan pengalaman nilai tidak sama pengertiannya. Kaitan konsep nilai, moral, dan norma dalam hubungan antara warga negara dengan negara sangat erat dan mempunyai pengaruh timbal balik.

- Konsep : Pengertian yang menunjuk kepada sesuatu. Pengertian ini tersebut dapat dinyatakan dalam bentuk kata-kata, nama atau pernyataan. Konsep didefinisikan sebagai kata yang menunjuk kepada sesuatu. Konsep Nilai adalah pengertian yang menunjuk pada nilai tertentu.

- Nilai : Sesuatu yang menunjuk kepada tuntunan perilaku yang membedakan perbuatan yang baik dan buruk atau dapat diartikan sebagai kualitas kebaikan yang melekat pada sesuatu.

- Moral : Keharusan perilaku yang dibawakan oleh nilai.

- Norma : Sumber dasar hukum yang menguatkan kedudukan konsep, nilai, dan moral serta perilaku yang dilakukan.

Mengubah sikap seseorang tidak mudah, tapi memerlukan proses dan kebiasaankebiasaan yang mendukung kearah itu pula. Mengenai hal tersebut ada beberapa pendekatan yang kita kenal :

1. Pendekatan emosional bertujuan menggugah perasaan dan emosi siswa dalam memahami, menghayati dan meyakini nilai yang akan ditanamkan.

2. Pendekatan rasional bertujuan memberikan peranan kepada akal dalam memahami dan menerima kebenaran nilai tersebut.

Untuk menyampaikan hal-hal tersebut, tidak hanya dengan informasi tetapi kita sebagai guru harus melakukan seperti apa yang diharapkan.

Tujuan pendidikan Nasional diperjelas dalam pasal 36 ayat (3) Undang-undang Nomor 20 Tahun 2003 tentang sistem Pendidikan Nasional, yang mengatur tentang kurikulum. Dinyatakan bahwa kurikulum disusun sesuai dengan jenjang pendidikan dalam kerangka Negara Kesatuan Republik Indonesia dengan memperhatikan :

1. Peningkatan iman dan taqwa;

2. Peningkatan akhlak mulia;

3. Peningkatan potensi, kecerdasan, dan minat peserta didik;

4. Keragaman potensi daerah dan lingkungan;

5. Tuntutan pembangunan daerah dan nasional;

6. Tuntutan dunia kerja;

7. Perkembangan ilmu pengetahuan, teknologi, dan seni;

8. Agama;

9. Dinamika pembangunan global;

10. Persatuan nasional dan nilai-nilai kebangsaan.

Esensi dari rumusan tujuan Pendidikan Nasional tersebut, meliputi :

1. Beriman dan bertaqwa terhadap Tuhan Yang Maha Esa, 
2. Mengembangkan potensi peserta didik,

3. Berakhlak mulia,

4. Sehat,

5. Berilmu,

6. Cakap,

7. Kreatif,

8. Mandiri, dan

9. Menjadi warga Negara yang demokratis serta bertanggung jawab.

Di bidang Ekonomi berlandaskan pada Pasal 33 UUD 1945. Bahwa cara pandang Integralistik Indonesia di bidang perekonomian ini menurut beberapa unsur di antaranya berikut ini.

1. Perkonomian disusun sebagai usaha bersama, maksudnya produksi dikerjakan oleh semua untuk semua di bawah pimpinan anggota masyarakat.

2. Perekonomian disusun atas kekeluargaan, maksudnya kemakmuran masyarakat yang diutamakan, bukan kemakmuran orang-orang. Oleh karena itu cabang produksi yang penting bagi negara dikuasai oleh negara bila tidak demikian maka tempat produksi akan jatuh ke tangan orang seorang, yang akan berkuasa dan rakyat banyak ditindasnya.

Hakikat Pembangunan Nasional adalah pembangunan manusia Indonesia seutuhnya dan pembangunan seluruh masyarakat Indonesia yang mengandung berikut ini.

1. Adanya keselarasan, keserasian, dan kebulatan yang utuh dalam seluruh kegiatan Pembangunan. Meskipun Pembangunan ekonomi mendapat tempat utama dalam Pembangunan Nasional dewasa ini dan di dalam jangka jangka panjang, unsur manusia, unsur sosial budaya dan unsur lainnya mendapat perhatian seimbang.

2. Pembangunan merata untuk seluruh masyarakat dan seluruh wilayah tanah air.

3. Hal yang ingin dibangun manusia dan masyarakat Indonesia sehingga pembangunan harus berkepribadian Indonesia dan menghasilkan manusia dan masyarakat maju yang tetap berkepribadian Indonesia pula.

Demikian pula di bidang-bidang lainnya (sosial budaya dan pertahanan keamanan) peran serta aktif warga negara sangat diperlukan.

Tiap warga negara memiliki kewajiban dan tanggung jawab terhadap negara, terutama peran serta dalam pembangunan. Pembangunan mengandung arti bahwa warga negara adalah objek dan subjek pembangunan karena warga negara sebagai subjek pembangunan maka warga negara sebagai manusia harus diperhitungkan. Oleh karena itu, perlu mengajak subjek pembangunan untuk berpartisipasi aktif dalam pembangunan.

\section{KEGIATAN BELAJAR 2 \\ KONSEP, NILAI, MORAL, DAN NORMA (KNMN) DALAM HUBUNGANNYA DENGAN SESAMA WARGA NEGARA}

Secara kodrat manusia dilahirkan ke bumi ini sebagai makhluk sosial (Zoon Politicon). Ia Secara kodrat manusia dilahirkan ke bumi ini sebagai makhluk sosial. Dari sekian banyak kebutuhan manusia tak satu pun yang dapat terpenuhi sendiri tanpa 
bantuan orang lain. Oleh karena itu, salah satu upaya yang dilakukan dalam rangka memenuhi kebutuhan hidupnya manusia adalah membangun suatu wadah tempat mereka berlindung yang dinamakan Negara. Begitu pula secara otomatis mereka menjadi anggota dari organisasi tersebut dari keanggotaan mereka dalam organisasi Negara, kitasebut "Warga Negara".

Menurut Rustandi (1988:60) "Warga Negara ialah mereka yang berdasarkan hukum merupakan anggota dari suatu negara". Mereka yang tidak termasuk Warga Negara disebut orang asing (bukan warga negara). Dari rumusan tersebut dapat disimpulkan bahwa dapat dikatakan sebagai Warga Negara maka seseorang harus dinyatakan secara legal (sah) menjadi Warga Negara. Sedangkan menurut pasal 26 ayat 1 dan 2 yang menjadi WNI adalah sebagai berikut:

1. Orang - orang bangsa Indonesia asli.

2. Orang - orang bangsa lain yang disahkan dengan undang - undang sebagai warga Negara Indonesia.

Orang - orang bangsa Indonesia asli adalah orang - orang yang dilahirkan oleh orang tua yang berasal dari seluruh wilayah Indonesia yang tersebar dari Sabang sampai Merauke.Sedangkan orang - orang bangsa lain adalah orang - orang peranakan yang bertempat kedudukan di Indonesia, mengakui Indonesia sebagai tanah airnya dan bersikap setia kepada Negara Republik Indonesia.

Warga Negara Republik yang terdiri dari beraneka ragam suku, bangsa, agama, dan keyakinan, budaya dan adat istiadat, memerlukan adanya kesadaran yang cukup tinggi dalam hubungannya sesama warga Negara. Oleh karena itu perlu adanya penanaman dan membiasakan sikap yang berlandaskan nilai - nilai pancasila dalam kehidupan sehari - hari sangat perlu dari usia dini dalam rangka pembinaan dan pembentukan pribadi warga Negara. Dengan pembentukan sikap yang berlandaskan nilai - nilai pancasila maka akan terbentuklah warga Negara yang baik.

* Ciri - ciri warga Negara yang baik antara lain:

1. Patriotik

2. Loyal terhadap bangsa dan Negara

3. Toleran beragama

4. Demokratis

Apabila sebagai warga Negara Indonesia tidak ditanamkan pembentukan sikap dan nilai yang baik maka akan menimbulkan dampak negatif seperti kenakalan remaja. Oleh karena itu dapat disimpulkan bahwa lembaga pendidikan (sekolah) berperan penting dalam penanaman nilai dan pembentukan sikap seseorang.

Mengapa penanaman nilai dalam rangka pembentukan sikap warga Negara perlu diterapkan dalam kehidupan sehari - hari karena kecerdasan yang tinggi tanpa dibarengi moralitas yang baik, mungkin akan berbahaya bagi diri dan umat manusia. Bagaimana manusia bersikap, dan melakukan perbuatan lahir dan batin sebagai dorongan kehendak yang didasarkan atas putusan akal, rasa, dan kehendak sikap, perkataan dan perbuatan tersebut senantiasa diarahkan kepada kebenarandan kebaikan. Pada diri manusia harus selalu ada kemampuan untuk menyelenggarakan kerjasama akal, rasa, dan kehendak itu dalam hubungan kesatuan, akal ialah yang memberikan pengetahuan tentang perbuatan bagaimana yang harus dilakukan, rasa yang mengujinya dengan berpedoman kepada 
hasratnya sendiri, sedangkan kehendaklah yang menentukan sikap akan dilakukan atau tidaknya.

* Landasan utama yang dijadikan pedoman tuntunan menjadi warga negara:

1. LandasanIdiil Pancasila

2. Landasan Struktural

3. Landasan Operasional

\section{KEGIATAN BELAJAR 3}

\section{Konsep Nilai, Moral, dan Norma (KNMN) Dalam Pengembangan Komitmen Bela Negara}

Bela Negara dapat terwujud bila dilandasi oleh adanya tekad, sikap dan tindakan warga Negara yang teratur, menyeluruh, terpadu dan berlanjut didasarkan oleh:

1. Kecintaan pada tanah air

2. Kesadaran berbangsa dan bernegara Indonesia

3. Keyakinan akan kesaktian pancasila sebagai ideologi Negara, dan kerelaan berkorban

Hak, kewajiban dan kehormatan untuk ikut serta dalam usaha pembelaan Negara bagi setiap warga negara harus dilaksanakan, oleh karenanya warga Negara harus memiliki wawasan aspek berkehidupan berbangsa dan bernegara. Wawasan nusantara merupakan suatu pandangan, sikap pendidikan dan keyakinan bangsa Indonesia yang telah lama dikenal dan dianutnya, bahkan telah mempunyai legalitas dalam kehidupan kita sebagai Bangsa dan Negara yang telah merdeka dan berdaulat.

* Wawasan dalam tujuan pembangunan nasional adalah wawasan nusantara yang mencakup:

1. Perwujudan kepulauan Nusantara sebagai satu kesatuan politik.

2. Perwujudan kepulauan Nusantara sebagai satu kesatuan ekonomi.

3. Perwujudan kepulauan Nusantara sebagai satu kesatuan sosial dan budaya.

4. Perwujudan kepulauan Nusantara sebagai satu kesatuan pertahanan dan keamanan.

Disamping meliputi aspek sosial dalam berkehidupan berbangsa dan bernegara tersebut, juga tidak kalah pentingnya dengan aspek alamiah TRIGATRA yang meliputi:

1. Letak geografis pada posisi silang

2. Keadaan dan kekayaan alam

3. Keadaan dan kemampuan penduduk

Cita - cita perjuangan bangsa yaitu mewujudkan Negara Kesatuan Republik Indonesia yang merdeka, bersatu, berdaulat, adil dan makmur berdasarkan pancasiladan UUD 1945. Untuk mewujudkan cita - cita bangsa tersebut perlu dipelihara adanya kepentingan nasional demi tegaknya Negara Kesatuan Republik Indonesia serta terwujudnya tujuan nasional melalui pembangunan nasional. 
Upaya bangsa untuk menjamin kepentingan nasional, dan tentu perlu diimbangi dengan upaya mewujudkan bela Negara bagi setiap warganya, yang dapat dilukiskan sebagai berikut:

Berdasarkan pasal 30 ayat 1 "Tiap warga Negara berhak dan wajib ikut serta dalam usaha pembelaan Negara"

Terwujudnya keikutsertaan warga Negara tersebut apabila warga Negara menyadari bahwa dia memiliki hak dan kewajiban yang harus dipersiapkan/ditumbuhkan, melalui upaya pendidikan khususnya Pendidikan Pendahuluan Bela Negara (PPBN).

* Ciri - ciri yang menjadi sasaran PPBN:

1. Cinta tanah air

2. Sadar berbangsa dan bernegara Indonesia

3. Yakin akan kebenaran dan kesaktian pancasila

4. Rela berkorban untuk bangsa dan Negara

5. Serta memiliki kemampuan awal bela Negara

Cinta tanah air yaitu yang mengenal dan mencintai wilayah nasionalnya sehingga selalu waspada serta siap membela tanah air terhadap ancaman, tantangan dan hambatan yang dapat membahayakan kelangsungan hidup bangsa dan Negara.

Sadar berbangsa dan bernegara Indonesia yaitu yang selalu membina, kerukunan, persatuan, kesatuan di lingkungan keluarga, masyarakat serta mencintai budaya bangsa.

Rela berkorban untuk bangsa dan Negara yaitu rela mengorbankan waktu, tenaga, pikiran, dan harta benda untuk kepentingan umum dan siap mengorbankan jiwa raga untuk kepentingan bangsa dan Negara.

Memiliki kemampuan awal bela Negara yaitu secara psikis memiliki sifat disiplin, ulet, kerja keras, mentaati peraturan perundang-undangan yang berlaku untuk mencapai tujuan nasional. Sedangkan secara fisik memiliki kondisi kesehatan, keterampilan jasmani untuk mendukung kemampuan awal bela Negara.

\section{Daftar Pustaka}

Sulfemi, Wahyu Bagja. (2017). Korelasi Penilaian Guru Terhadap Gaya Kepemimpinan Asertif Kepala Sekolah Dengan Kinerja Guru Di SMPN 01 Jasinga Kabupaten Bogor. Lingua : Jurnal ilmiah Kajian Pendidikan Bahasa dan Sastra Indonesia. 3 (1) 201 7.90-100

Sulfemi, Wahyu Bagja dan Hilga Minati. (2018). Meningkatkan Hasil Belajar Peserta Didik Kelas 3 SD Menggunakan Model Picture And Picture dan Media Gambar Seri. JPSD. 4 (2), 228- 242.

Sulfemi, Wahyu Bagja dan Setianingsih. (2018), Penggunaan Tames Games Tournament (TGT) Dengan Media Kartu Dalam Meningkatkan Hasil Belajar. Journal of Komodo Science Education (JKSE. 1 (1), 1-14 
Sulfemi, Wahyu Bagja dan Nurhasanah. (2018). Penggunaan Metode Demontrasi dan Media Audio Visual Dalam Meningkatkan Hasil Belajar Peserta Didik Mata Pelajaran IPS. Jurnal Pendas Mahakam. 3 (2). 151-158.

Sulfemi, Wahyu Bagja. (2018). Pengaruh Disiplin Ibadah Sholat, Lingkungan Sekolah, dan Intelegensi Terhadap Hasil Belajar Peserta Didik Mata Pelajaran Pendidikan Agama Islam. Edukasi: Jurnal Penelitian Pendidikan Agama dan Keagamaan. 16 (2), 166-178.

Sulfemi, Wahyu Bagja \& Desmiati, Z. (2018). Model Pembelajaran Missouri Mathematics Project Berbantu Media Relief Experience dalam Meningkatkan Hasil Belajar Siswa. Pendas Mahakam: Jurnal Pendidikan Dasar, 3(3), 232-245

Sulfemi, Wahyu Bagja. (2019). Model Pembelajaran Kooperatif Mind Mapping Berbantu Audio Visual Dalam Meningkatkan Minat, Motivasi dan Hasil Belajar IPS. Jurnal PIPSI (Jurnal Pendidikan IPS Indonesia), 4(1), 13-19.

Sulfemi, Wahyu Bagja dan Mayasari, Nova. (2019), Peranan Model Pembelajaran Value Clarification Technique Berbantuan Media Audio Visual Untuk Meningkatkan Hasil Belajar IPS. Jurnal Pendidikan. 20. (1). 53-68.

Sulfemi, Wahyu Bagja \& Yuliana, D. (2019). Penerapan Model Pembelajaran Discovery Learning Meningkatkan Motivasi dan Hasil Belajar Pendidikan Kewarganegaraan. Jurnal Rontal Keilmuan Pancasila dan Kewarganegaraan, 5(1), 17-30.

Sulfemi, Wahyu Bagja dan Yuliani, Nunung. (2019). Model Pembelajaran Contextual Teaching And Learning (CTL) Berbantu Media Miniatur Lingkungan Untuk Meningkatkan Hasil Belajar IPS. Edunomic : Jurnal Ilmiah Pendidikan Ekonomi Fakultas Keguruan Dan Ilmu Pendidikan. 7 (2) . 73-84

Sulfemi, Wahyu Bagja.(2019). Bergaul Tanpa Harus Menyakiti. Bogor : Visi Nusantara Maju

Sulfemi, Wahyu Bagja. (2019). Menanggulangi Prilaku Bullying Di Sekolah. Bogor : Visi Nusantara Maju.

Sulfemi, Wahyu Bagja (2019). Modul Pembelajaran Perundang-Undangan Pendidikan. Bogor : STKIP Muhammadiyah Bogor 